\title{
AVOIN JA JOUSTAVA AIKUISOPETUS
}

\author{
"'Mene ihmisten luo, \\ elä heidän kanssaan, \\ rakasta heitä \\ oppien heiltä. \\ Työstä sitä, mitä he tietävät, \\ rakenna sen päalle. \\ Työ on valmis, kun ihmiset sanovat: \\ Me sen teimme."
}

Torniossa kokoontui 10.-14. syyskuuta Euroopan Neuvoston seminaari "Avoin ja joustava aikuiskoulutus'. Osanottajat, yhteensä 34 aikuiskoulutuksen hallinto-, suunnittelu- ja tutkimustehtävissä toimivaa henkilöä, edustivat kahdeksaa Euroopan maata.

Seminaarin kokoontumispaikaksi oli valittu Lapin läänin pieni mutta vireä koulukaupunki Tornio sen takia, että siellä voitiin esitellä Lapin läänin aikuiskoulutuskokeilun eli LAIKOn tuloksia. Kokeilua on aiemmin esitelty tämän lehden numerossa $1 / 90$, joten tässä kirjoituksessa ei selosteta kokeilua sinänsä, vaan sen herättämiä mielipiteitä ja näkemyksiä. Lisäksi seminaarissa esiteltiin kokemuksia verkostotyöskentelystä ja yhteisön kehittämisestä.

\section{Mitä voimme oppia LAIKOsta?}

Suomessa hallintoviranomaiset ovat vähitellen oppineet luottamaan siihen, että koulutusratkaisut voidaan tehdä muuallakin kuin pääkaupungin keskusvirastossa. Päätösvaltaa siirrettiin LAIKOn yhteydessä lääninhallitukselle ja koulut vedettiin mukaan suunnittelutyöhön.

Laiko-kokeilun tavoite oli jo ammatissa toimivien aikuisten koulutustason nostaminen ja työllisyyden parantaminen. Tavoite saavutettiin osittain: Teknologian tarjoamien apuvälineiden avulla saatiin koulutukseen aikuisväestöä, joka ei muutoin olisi voinut lähteä koulutukseen. Työllisyyden parantaminen sen sijaan ei onnistunut yhtä hyvin.

Koulutus sinänsä ei parantanut työllisyyttä, yritysjohtajia, jotta he luovat uusia työpaikkoja. Kausityöttömyyttä taas voitiin vähentää siten, että työntekijä hankki useamman ammattitaidon.

Koulutusta suunniteltaessa todettiin, että raja yleissivistävän ja ammatillisen koulutuksen välillä on veteen piirretty viiva, varsinkin sen jälkeen kun vastaavat keskusvirastot on yhdistetty. Erityisesti kielitaito, joka perinteisesti on luettu yleissivistykseen kuuluvaksi, on nykyään monille ammatissa toimimisen ehto.

\section{Aikuinenkin tarvitsee tukea}

Osoittautui, että työtön aikuinen tarvitsee koulutuspäätöksensä tueksi tietoa saatavilla olevista vaihtoehdoista ja taloudelliset resurssit; lisäksi hänelle tulee laatia koulutus- ja urasuunnitelma. Toistaiseksi on vielä ratkaisematta, mikä olisi tukea antavan organisaation paikka hallinnossa. Koulutuksen aikana paras tuki tulee opettajalta ja toisaalta pienryhmän jäseniltä.

Lapin harvaan asutulla alueella käytettiin koulutuksen saatavuuden varmistamiseksi runsaasti teknisiä laitteita: tietokoneita, neuvottelupuhelinta, telekopiota. Seminaarin osanottajat keskustelivat vilkkaasti juuri tekniikan käytöstä aikuiskoulutuksessa. Tekniikan käyttö omaksuttiin totuttelun jälkeen suhteellisen helposti. Kalliin hankintahinnan ja korkeiden käyttökustannusten vuoksi tekniikka ei kuitenkaan ole ratkaisu köyhien maiden ongelmiin, totesi mm. Jugoslavian edustaja. Suomessakin on vaikea löytää rahoitusta, kun käyttökelpoisiksi havaittuja teknisiä apuvälineitä haluttaisiin myöhemmin käyttää. 
Turkin edustaja, professori Sudi Bülbül Ankarasta katsoi, että LAIKOn yhteydessä käytetyt laitteet ovat aivan liian monimutkaisia ja kalliita hänen kotimaahansa, jossa 30 prosenttia väestöstä on lukutaidotonta. Norjan edustaja puolestaan painotti sitä, että ongelma ei ole niinkään korkeissa kustannuksissa, vaan yksilötason ongelmissa: Miten saamme vanhemmat ihmiset koulutukseen? Miten madaltaisimme kynnystä niin, että alhaisen pohjakoulutuksen omaavat uskaltautuvat mukaan?

Irlannin edustaja, Deirdre Frawley painotti teknologian ja aikuiskoulutuksen merkitystä siinä, että ihmiset eivät jäisi yhteiskunnan ja kehityksen ulkopuolelle. Varsinkin Irlannin tapaisessa luokkajakoisessa yhteiskunnassa osa ihmisistä on joutunut marginaalitilanteeseen: he ovat vailla riiittävää koulutusta ja osittain siksi työttömiä. Moderni teknologia voi auttaa ihmisiä osallistumaan oppimisprosessiin.

\section{Yhteisön kehittämistyöllä oman elämänsä herraksi}

Irlannissa toteutettu yhteisön kehittämisohjelma tähtää siihen, että ihmiset voivat oppia aikuisina yleissivistyksen ja ammattitaitojen ohessa myös viestintä-, päätöksenteko-, ongelmaratkaisu- ja organisaatiotaitoja. He oppivat ratkaisemaan yhteisössään ja omassa elämässään ilmeneviä ongelmia ja saavat näin itseluottamusta. Yhteisön kehittämistyön tavoitteena on yhteiskuntaan aktiivisesti suhtautuva kansalainen.

Aikuiskoulutusta antavat oppilaitokset joutuvat uuteen tilanteeseen: Niiden on etsittävä oma erikoisalansa ja kehitettävä sopivat opetusmenetelmät esimerkiksi monimuoto-opetuksen antamiseen. Kustannusten karsimiseksi ja asiantuntemuksen hyödyntämiseksi oppilaitosten on tehtävä yhteistyötä. Toisaalta ne joutuvat kilpailemaan koulutettavista. - Koulutuksesta on tullut tuote ja se saattaa joutua kansainväliseen kilpailuun.

\section{Aikuiskoulutus ihmisoikeutena}

Aikuiskoulutus ja jatkuvan, elinikäisen koulutuksen mahdollisuus kuuluu ihmisen perusoikeuksiin. Jatkuvan koulutuksen avulla ihminen sopeutuu nopeisiin 'muutoksiin ja saa keinot muokata oman tilansa yhteiskunnan tarpeita vastaavaksi. Näin arvioi Euroopan neuvoston sihteeristön jäsen Mehmet Ömat aikuiskoulutuksen merkitystä.

Seminaari pohti myös aikuiskoulutuksen prioriteettikysymyksiä. Eri maissa ongelmat vaihtelevat, mutta tärkeimmiksi ryhmiksi noussevat esimerkiksi maahanmuuttajat, funktionaalista lukutaitoa vailla olevat, saamenkieliset, lukiokoulutusta haluavat ja eri syistä syrjäytyvät tai heikosti koulutetut ryhmät. Yleissivistävää ja ammatillista koulutusta ei voi erottaa toisistaan, varsinkaan jos yleissivistyksen termiä laajennetaan merkitsemään kykyä elää, työskennellä ja kommunikoida muuttuvassa yhteiskunnassa.

Teknisiin laitteisiin ei tulisi kiinnittää liikaa huomiota; sen sijaan olisi mietittävä, miten sosiaalisia etäisyyksiä vähennetään ja koulutus saadaan ihmisten luo. Tarvitaan myös pedagogisten suhteiden muutosta demokraattiseen suuntaan. Etä- ja monimuoto-opetuksen tulisi olla mahdollisimman avointa ja joustavaa, onhan koulutuksen keskipisteenä aina aikuinen ihminen kykyineen ja toiveineen.

Seminaarin päätössanoissa Olavi Alkio totesi, että kokous on ollut aktiivisten ihmisten tilaisuus ja siihen kohdistuneet odotukset ovat hyvin täyttyneet. Mikä on kokouksen anti Euroopan neuvostolle, jää arvioitavaksi myöhemmin. 